\title{
PERANCANGAN SISTEM INFORMASI PENJUALAN KERAJINAN TANGAN LAMPU HIAS PADA PURNAMA SHOP BERBASIS WEB
}

\author{
Surminah11, Muhammad Fauzi Zulkarnaen2², Ichwan Purwata3 ${ }^{3}$ \\ 1,Program Studi Sistem Informasi \\ Sekolah Tinggi Menejmen Informatika dan Komputer STMIK Lombok \\ Jln. Basuki Rahmat No.105 Praya Lombok Tengah 83511 \\ ${ }^{1}$ surminah1@gmai.com, ${ }^{2}$ muhammadfauzizulkarnaen@gmail.com, ${ }^{3}$ ichwanpurwata2017@gmail.com
}

\begin{abstract}
Designing information systems for media sales of goods on purnama shop is currently still done manually. In getting information is still done manually. In getting information is still done by phone call, texting, WA and BBM so that there is a mistake in customer service.

The method used in writing this final assignment is the sdlc method (system development life cycle). This method includes analysis system, requirements specifications system, design system, development system, testing system, and implementation and maintenance syatems. In this sales information system that connects computers and customers via the internet.

The results of this final project is an information system for the media selling goods using computer media that will make it easier to record transaction data so that it becomes an effective promotional medium for business development. The data presented in this information system is ordering goods online. But further information uses an SMS where the seller informs the shipping cost of goods and goods sent.
\end{abstract}

Keywords: Php, Mysql, SDLC (System Development Life Cycle)

\section{Abstrak}

Perancangan sistem informasi untuk media penjualan barang pada purnama shop saat ini masih dilakukan secara manual. Dalam mendapatkan informasi masih dilakukan secara manual. Dalam mendapatkan informasi masih dilakukan dengan cara menelpon, sms, BBM, Whatsapp sehingga terjadi kekeliruan dalam pelayanan pelanggan.

Metode yang digunakan dalam penulisan tugas akhir ini adalah metode SDLC (System Development Life Cycle) metode ini mencakup tahapan yaitu analisis system, spesifikasi kebutuhan sistem, perancangan sistem, pengembanagan sistem, pengujian sistem, implementasi dan pemeliharaan sistem, di sistem informasi penjualan ini yang menghubungkan antara komputer dan pelanggan melalui internet.

Hasil dari tugas akhir ini adalah suatu sistem informasi untuk media penjualan barang dengan menggunakan media komputer yang akan mempermudah mencatat data transaksi sehingga menjadi media promosi yang efektif bagiperkembangan usaha. Data yang disajikan dalam system informasi ini berupa pemesanan barang secara online, tetapi informasi selanjutnya menggunakan sms dimana penjual menginformasikan biaya ongkos kirim barang dan barang sudah terkirim.

Kata Kunci : Php, Mysql dan SDLC (System Development Life Cycle)

\section{Pendahuluan}

Purnama Shop merupakan perusahaan yang bergerak di bidang penjualan dan pembuatan seni kerajinan tangan yang terbuat dari bahan dasar karang air tawar yang berlokasi di Jl. Gajah Mada Juring Leneng, Praya Lombok Tengah. Purnama Shop memproduksi berbagai macam lampu hias antara lain: lampu kamar, lampu gantung, lampu belajar, lampu tidur, dan lain sebagainya.

Produksi lampu hias pada saat ini sangatlah diminati oleh pasar lokal maupun internasional. Tetapi perkembangan penjualan lampu hias di toko ini masih melakukan penjualan secara manual ( tatap muka) sehingga 
konsumen harus datang ke lokasi untuk membeli atau pun melihat langsung produknya. Cara seperti ini akan berdampak pada kurang berkembangnya promosi lampu hias ke beberapa wilayah pasar. Di samping itu, jangkauan pemasaran yang sempit juga merupakan kendala yang dihadapi pihak toko.

Berdasarkan permasalahan di atas maka penulis mengambil judul tentang "Perancangan Sistem Informasi Penjualan Kerajinan Tangan Lampu Hias Pada Purnama Shop Berbasis Web".

\section{Tinjauan Pustaka}

"Perancangan Sistem Informasi Penjualan Pada Toko Ribo Jaya Ambon"[1]. Sama halnya dengan toko Ribo Jaya yang merupakan usaha dagang jual-beli pakaian, agar mampu menyediakan informasi yang tepat dan akurat dalam melakukan transaksinya. Sistem yang berjalan di toko Ribo Jaya saat ini masih dilakukan secara manual seperti pencatatan transaksi pembelian, pencatatan transaksi penjualan, pencarian barang, perhitungan stok, dan pembuatan laporan-laporan yang mana memerlukan waktu yang cukup lama dan resiko kesalahan manusia (human error) yang cukup besar.

“Analisis Perancangan Sistem Informasi Penjualan dan Pemesanan Plywood Berbasiskan Web Pada PT. Kumpeh Karya Lestari Jambi" [2]. Perusahaan kumpeh karya lestari jambi adalah perusahaan yang bergerak dalam penjualan bahan standart veneer dalam melakukan pemasaran dan proses penjualan menggunakan cara manual. Untuk memperbesar dalam menjual produk, penulis mencoba untuk membuat aplikasi penjualan online atau berbasis web.

Sanja Kurniawan "Perancangan Sistem Informasi Penjualan Helm Pada Toko Helm Swaka Pacitan " [3], Perancangan Sitem Informasi Penjualan Helm Pada Toko Helm Swaka Pacitan, penulis hanya merancang suatu sistem, dan kedepannya diharapkan bisa untuk dikembangkan menjadi program yang bisa berguna bagi pihak instansi Toko Helm Swaka Pacitan.

Perancangan Sistem Informasi penjualan Handphone Berbasis Web (Studi Kasus Pada Toko Ilham Celluler Jakarta)[4], Pada toko ilham celluler, pencatatan dan pengolahan data barang, jumlah dan harga barang, serta data transaksi penjualan masih dilakukan dengan menggunakan tulisan tangan. Kesulitan dalam mencatat dan menghitung banyaknya jenis barang, jumlah barang, maupun besarnya jumlah harga, mengakibatkan data yang diperoleh menjadi kurang akurat. Untuk meningkatkan keakuratan data, diperlukan pembangunan sistem informasi penjualan barang yang terkomputerisasi. Aplikasi Sistem Informasi Penjualan Handphone Berbasis Dekstop ini dibuat dengan menggunakan bahasa pemrograman java, software menggunakan Netbeans IDE 7.0 sebagai pembuat interface utama dan MySQL sebagai basis datanya.

Sistem Informasi Penjualan dan Pemesanan Produk Berbasis Web" [5], hasil dari penelitian diharapkan sistempenjualan dan pemesanan prodak berbasis web ini, konsumen dapat memesan produk dimana saja dan kapan saja yang terhubung dengan jaringan internet, dan konsumen hanya perlu mendaftar dan melakukan login kemudian melakukan pemilihan produk dan memulai memesan.

\section{Metodologi Penelitian}

\section{a. Analisis SWOT}

Analisis SWOT menurut Jogiyanto (2005:46) sangat diperlukan dalam menilai kekuatan maupun kelemahan dari sumber daya yang dimiliki oleh perusahaan serta menilai kesempatan eksternal maupun tantangan yang di hadapi. Analisis swot mempunyai tahapantahapan sebagai berikut (strength) Kekuatan, (weaknes) Kelemahan, (opportunity) Peluang, dan, (threats) Ancaman. [6].

Tabel 3.1 analisis SWOT

\begin{tabular}{|c|c|c|}
\hline No & Analisis & Sistem Berjalan \\
\hline 1 & $\begin{array}{l}\text { Strength } \\
\text { Kekuatan }\end{array}$ & $\begin{array}{l}\text { 1. SDM mampu } \\
\text { mengoprasikan sistem yang } \\
\text { akan diusulkan } \\
\text { 2. Tersedianya fasilitas untuk } \\
\text { membangun sistem yang } \\
\text { akan diusulkan misalnya } \\
\text { dari segi biaya atau alat }\end{array}$ \\
\hline 2 & $\begin{array}{l}\text { Weaknesess } \\
\text { Kelemahan }\end{array}$ & $\begin{array}{l}\text { 1. Dibutuhkan penyesuaian } \\
\text { dari sistem lama dengan } \\
\text { yang baru } \\
\text { 2. Perlu adanya bidang ahli } \\
\text { yang menguasai bidang } \\
\text { komputer untuk mengolah } \\
\text { data pada sistem yang } \\
\text { diusulkan }\end{array}$ \\
\hline
\end{tabular}




\begin{tabular}{|c|c|c|}
\hline 3 & $\begin{array}{l}\text { Opportunity } \\
\text { Peluang }\end{array}$ & $\begin{array}{l}\text { 1. Mempermudah pekerjaan } \\
\text { penjual dalam mengolah } \\
\text { penjualan barang, } \\
\text { pembelian barang, stok } \\
\text { barang dan transaksi } \\
\text { barang } \\
\text { 2. Dapat memberikan } \\
\text { informasi dengan cepat dan } \\
\text { akurat } \\
\text { 3. Membuat sistem yang } \\
\text { terkomputerisasi yang } \\
\text { dapat dipakai oleh siapa } \\
\text { saja yang mempunyai hak } \\
\text { akses ke sistem tersebut }\end{array}$ \\
\hline 4 & $\begin{array}{l}\text { Threats } \\
\text { Ancaman }\end{array}$ & $\begin{array}{l}\text { 1. Adanya ancaman virus atau } \\
\text { cracking } \\
\text { 2. Jaringan internet yang } \\
\text { kurang stabil }\end{array}$ \\
\hline
\end{tabular}

b. diagram alir system

Tabel 3.2 Flowmap Sistem Usulan

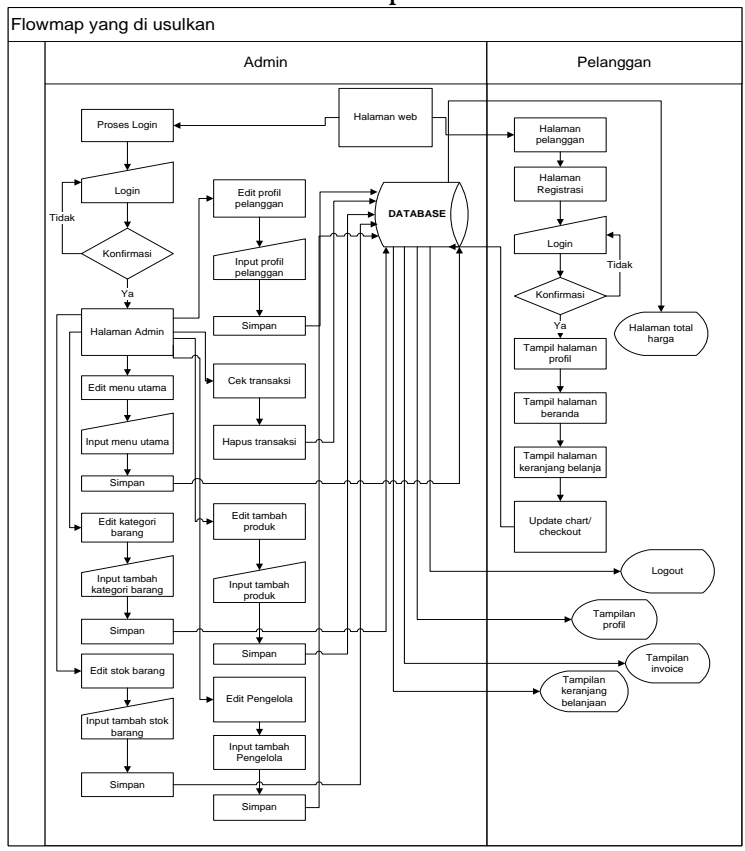

1. Kemudian akan tampil halaman administrator disana admin bisa melakukan edit menu utama, edit cara pemesanan, edit kategori produk, edit sub menu, edit profil, cek transaksi, edit tambah produk

2. Kemudian pembeli atau pelanggan membuka halaman pemesanan

3. Kemudian di halaman pemesanan terdapa pengisian data pelanggan dan memilih barang yang dibutuhkan
4. Kemudian order barang tersebut disimpan di database

c. Perancangan Proses

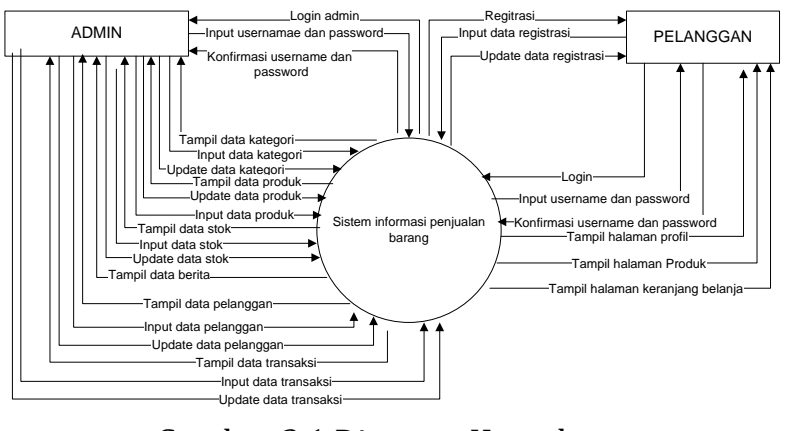

Gambar 3.1 Diagram Konteks

\section{Hasil dan Pembahasan}

\subsection{Tampilan Halaman Web}

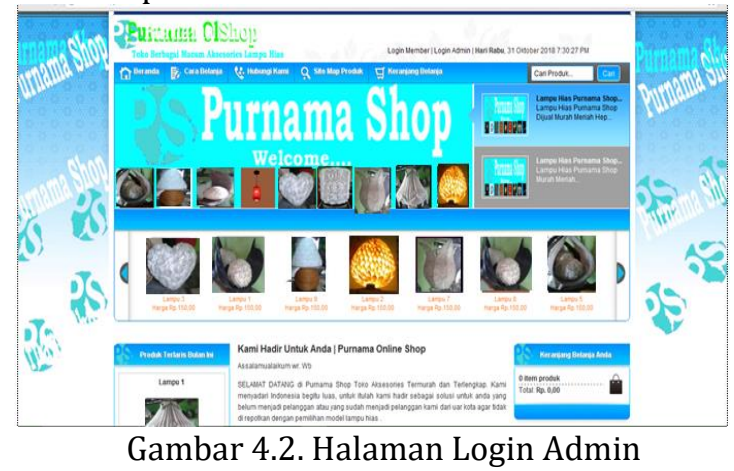

4.2. Halaman Login Pelanggan

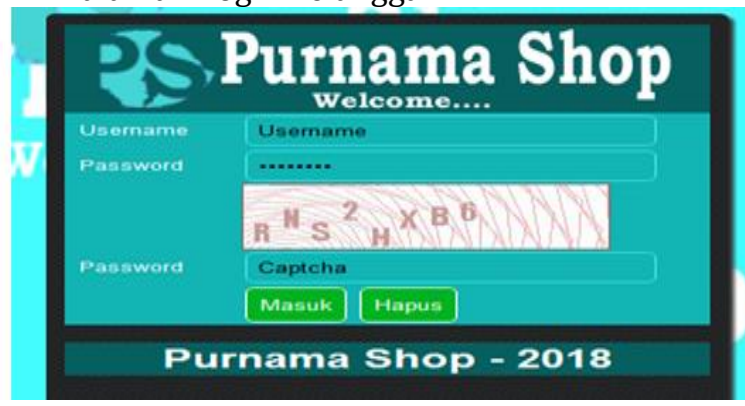

Gambar 4.3 Login Pelanggan

Login Admin adalah halaman pertama sebelum admin masuk ke sistem dan mengolah data, dalam menu login ini admin diminta untuk menginputkan username, password, dan capthca dengan benar pada form user dan password. Jika terjadi kesalahan sistem akan menampilkan tampilan awal login hal ini terjadi dikarenakan saat login admin menginputkan username dan password yang tidak benar atau username dan password yang diinpukan belum terdaftar pada 
database sehingga inputan tersebut tidak memiliki hak akses kedalam sistem tersebut.

\subsection{Halaman Login Pelanggan}

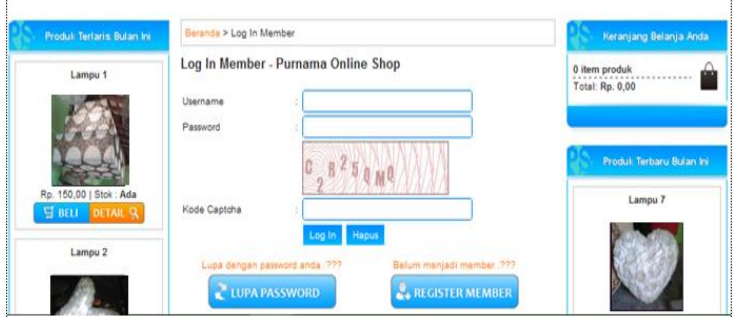

Gambar 4.4 Login Pelanggan

Login Pelanggan adalah halaman untuk masuk ke sistem dan mengolah data, dalam menu login ini pelanggan diminta untuk menginputkan username dan password dengan benar pada form user dan password. Jika terjadi kesalahan sistem akan menampilkan tampilan awal login hal ini terjadi dikarenakan saat login user menginputkan username dan password yang tidak benar atau username dan password yang diinpukan belum terdaftar pada database sehingga inputan tersebut tidak memiliki hak akses kedalam sistem tersebut.

\subsection{Halaman Registrasi}
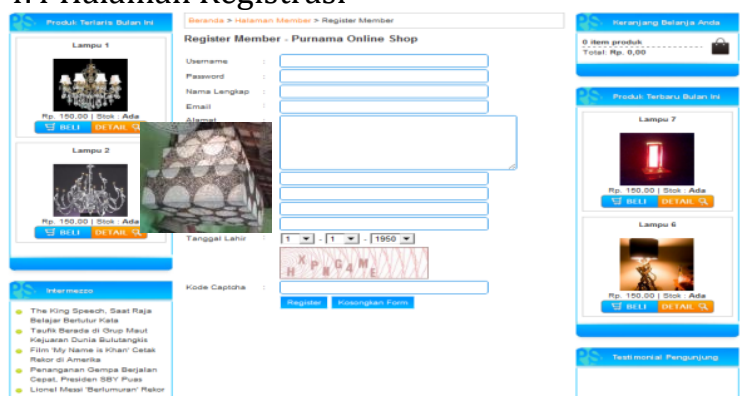

Gambar 4.5 Halaman Registrasi

tampilan registrasi pelanggan, dimana pada halaman ini pelanggan akan melakukan registrasi terlebih dahulu sebelum login.

\subsection{Halaman Produk}

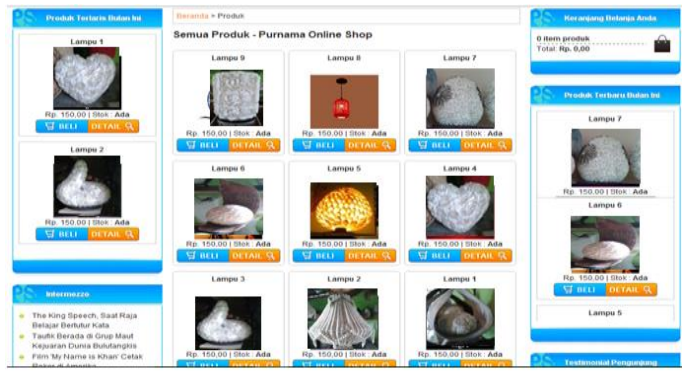

Gambar 4.6 Halaman Produk halaman utama yang dimana halaman utama ini muncul saat admin dan user berhasil masuk ke sistem.

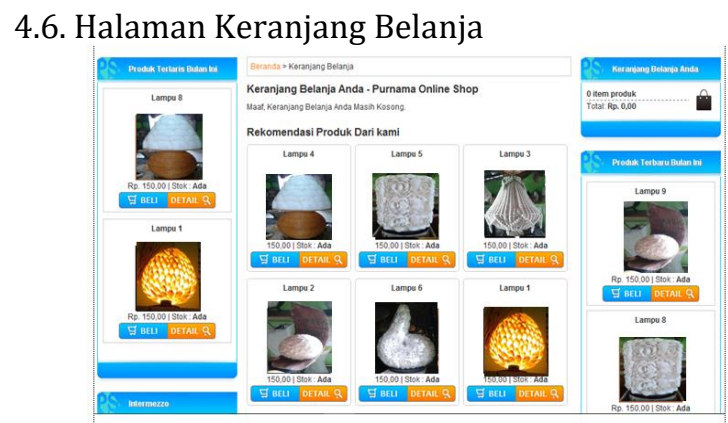

Gambar 4.7 Halaman Keranjang Belanja

tampilan halaman keranjang belanja, dimana pada halaman ini pelanggan bisa melihat jumlah belanjaan yang sudah dilakukan oleh pelanggan, jika pelanggan akan melanjutkan belanja maka pelanggan bisa mengkelik kategori barang yang ada dihalaman atas kanan tampilan.

\subsection{Testing}

\section{Black BoxTesting}

Pengujian black box merupakan pendekatan komplementer dari teknik white box, karena pengujian black box diharapkan mampu mengungkap kelas kesalahan yang lebih luas dibandingkan teknik white box. Pengujian black box berfokus pada pengujian persyaratan fungsional perangkat lunak, untuk mendapatkan serangkaian kondisi input yang sesuai dengan persyaratan fungsional suatu program. Pengujian black box berfokus persyaratan fungsional perangkat lunak. Pengujian black box adalah pengujian aspek fundamental system tanpa memperhatikan struktur logika internal perangkat lunak. Metode ini digunakan untuk mengetahui apakah perangkat lunak berfungsi dengan benar.

Pengujian black box merupakan metode perancangan data uji yang didasarkan pada spesifikasi perangkat lunak. Data uji dibangkitkan, dieksekusi pada perangkat lunak dan dan kemudian keluaran dari perangkat lunak dicek apakah telah sesuai dengan yang diharapkan.

Pengujian ini berusaha menemukan kesalahan antara lain:

1. Fungsi-fungsi yang tidak benar atau hilang

2. Kesalahan interface

3. Kesalahan kinerja 


\section{Kesalahan dalam struktur data}

\subsubsection{Rencana pengujian}

Pengujian aplikasi sistem informasi untuk media penjualan barang menggunakan data uji berdasarkan data yang telah didapat dari aplikasi.

Rencana pengujian selengkapnya dapat dilihat pada tabel 4.1 :

Tabel 4.1 Rencana Pengujian Aplikasi system informasi kenaikan pangkat

\begin{tabular}{|c|c|c|c|}
\hline No & Item Uji & $\begin{array}{l}\text { Detail } \\
\text { Pengujian }\end{array}$ & $\begin{array}{l}\text { Jenis } \\
\text { Pengujian }\end{array}$ \\
\hline 1 & Login User & $\begin{array}{l}\text { Verifikasi } \\
\text { data login } \\
\text { user dengan } \\
\text { memasukkan } \\
\text { username } \\
\text { dan } \\
\text { password } \\
\text { oleh admin }\end{array}$ & Black Box \\
\hline \multirow[t]{3}{*}{2} & \multirow[t]{3}{*}{$\begin{array}{l}\text { Pengujian } \\
\text { input data } \\
\text { produk }\end{array}$} & $\begin{array}{l}\text { Proses } \\
\text { pengisian } \\
\text { data produk } \\
\text { sekaligus } \\
\text { proses } \\
\text { simpan }\end{array}$ & Black Box \\
\hline & & $\begin{array}{l}\text { Proses hapus } \\
\text { data produk }\end{array}$ & Black Box \\
\hline & & $\begin{array}{l}\text { Proses ubah } \\
\text { data produk }\end{array}$ & Black Box \\
\hline \multirow[t]{2}{*}{3} & \multirow[t]{2}{*}{$\begin{array}{l}\text { Menginputkan } \\
\text { data kategori } \\
\text { produk }\end{array}$} & $\begin{array}{l}\text { Menampilkan } \\
\text { gambar, } \\
\text { nama } \\
\text { produk, } \\
\text { keterangan } \\
\text { produk, } \\
\text { harga barang, } \\
\text { stok barang, } \\
\text { total harga } \\
\text { barang }\end{array}$ & Black Box \\
\hline & & $\begin{array}{l}\text { Mengisi } \\
\text { semua } \\
\text { produk dan } \\
\text { kategori } \\
\text { barang }\end{array}$ & Black Box \\
\hline
\end{tabular}

\begin{tabular}{|l|l|l|l|}
\hline \multirow{2}{*}{} & & $\begin{array}{l}\text { Proses } \\
\text { pengisian } \\
\text { nilai perilaku } \\
\text { kerja }\end{array}$ & Black Box \\
\cline { 3 - 4 } & $\begin{array}{l}\text { Menampilkan } \\
\text { invoice total } \\
\text { harga produk } \\
\text { simpan }\end{array}$ & $\begin{array}{l}\text { Menampilkan } \\
\text { total harga } \\
\text { barang, } \\
\text { banyak } \\
\text { barang, dan } \\
\text { tanggal } \\
\text { transaksi, } \\
\text { tanggal kirim } \\
\text { barang }\end{array}$ & Black Box \\
& & Black Box \\
& & $\begin{array}{l}\text { Hapus data } \\
\text { invoice }\end{array}$ & Black Box \\
& & \\
& & \\
& &
\end{tabular}

\subsubsection{Kasus Dan Hasil Pengujian}

Berdasarkan rencana pengujian yang telah disusun, maka dapat dilakukan pengujian sebagai berikut.

\section{a. Pengujian Login}

1. Login sebagai admin

Hasil dari pengujian login dapat dilihat pada tabel 4.2 berikut ini adalah tabel hasil pengujian login:

Tabel 4.2 Tabel Pengujian login admin

\begin{tabular}{|c|c|c|c|}
\hline \multicolumn{4}{|c|}{ Kasus dan hasil uji (data normal) } \\
\hline $\begin{array}{l}\text { Data } \\
\text { masukan }\end{array}$ & $\begin{array}{l}\text { Yang } \\
\text { diharapkan }\end{array}$ & Pengamatan & Kesimpulan \\
\hline $\begin{array}{l}\text { Username } \\
\text { (admin) } \\
\text { password } \\
\text { (admin) }\end{array}$ & $\begin{array}{l}\text { Dapat } \\
\text { masuk } \\
\text { kehalaman } \\
\text { menu } \\
\text { utama }\end{array}$ & $\begin{array}{l}\text { Tampil } \\
\text { menu } \\
\text { utama } \\
\text { sesuai } \\
\text { dengan hak } \\
\text { akses }\end{array}$ & Diterima \\
\hline & & nal) & \\
\hline
\end{tabular}




\begin{tabular}{|l|l|l|l|}
\hline $\begin{array}{l}\text { Data } \\
\text { masukan }\end{array}$ & $\begin{array}{l}\text { Yang } \\
\text { diharapkan }\end{array}$ & Pengamatan & Kesimpulan \\
\hline $\begin{array}{l}\text { Data salah } \\
\text { contoh: } \\
\text { username } \\
\text { (admin) } \\
\text { password } \\
\text { (1234) }\end{array}$ & $\begin{array}{l}\text { Tidak dapat } \\
\text { login } \\
\text { sebagai } \\
\text { admin dan } \\
\text { akan tampil } \\
\text { menu login } \\
\text { awal }\end{array}$ & $\begin{array}{l}\text { Tampil } \\
\text { menu } \\
\text { utama tidak } \\
\text { sesuai } \\
\text { dengan hak } \\
\text { akses }\end{array}$ & $\begin{array}{l}\text { Tidak } \\
\text { diterima }\end{array}$ \\
& & & \\
\hline
\end{tabular}

\section{b. Pengujian Input Data Produk, Kategori, dan Stok Barang}

Hasil dari pengujian input data produk dapat dilihat pada tabel 4.3. berikut ini adalah tabel hasil pengujian input data produk:

Tabel 4.3 Tabel Pengujian Input Data Produk, Kategori, dan Stok Barang

\begin{tabular}{|c|c|c|c|}
\hline $\begin{array}{l}\text { Data } \\
\text { Masuka } \\
\text { n }\end{array}$ & $\begin{array}{l}\text { Yang } \\
\text { Diharapka } \\
\mathrm{n}\end{array}$ & $\begin{array}{l}\text { Pengamata } \\
\mathrm{n}\end{array}$ & $\begin{array}{l}\text { Kesimpula } \\
\mathrm{n}\end{array}$ \\
\hline $\begin{array}{l}\text { Input } \\
\text { data } \\
\text { produk }\end{array}$ & $\begin{array}{l}\text { Dapat } \\
\text { masuk ke } \\
\text { data } \\
\text { produk } \\
\text { dan } \\
\text { tambah } \\
\text { data } \\
\text { produk, } \\
\text { data } \\
\text { kategori, } \\
\text { dan data } \\
\text { stok } \\
\text { barang }\end{array}$ & $\begin{array}{l}\text { Pengisian } \\
\text { sesuai } \\
\text { dengan } \\
\text { yang } \\
\text { diharapkan }\end{array}$ & Diterima \\
\hline $\begin{array}{l}\text { Klik } \\
\text { tombol } \\
\text { simpan }\end{array}$ & $\begin{array}{l}\text { Data } \\
\text { tersimpan } \\
\text { ke dalam } \\
\text { database } \\
\text { dan } \\
\text { muncul } \\
\text { pada data } \\
\text { yang ada }\end{array}$ & $\begin{array}{l}\text { Tombol } \\
\text { simpan } \\
\text { sesuai } \\
\text { dengan } \\
\text { yang } \\
\text { diharapkan }\end{array}$ & Diterima \\
\hline $\begin{array}{l}\text { Klik } \\
\text { tombol } \\
\text { edit }\end{array}$ & $\begin{array}{l}\text { Dapat } \\
\text { masuk ke } \\
\text { dalam } \\
\text { form edit } \\
\text { data }\end{array}$ & $\begin{array}{l}\text { Tombol } \\
\text { edit sesuai } \\
\text { dengan } \\
\text { yang } \\
\text { diharapkan }\end{array}$ & Diterima \\
\hline
\end{tabular}

\begin{tabular}{|l|l|l|l|}
\hline $\begin{array}{l}\text { Klik } \\
\text { tombol } \\
\text { hapus }\end{array}$ & $\begin{array}{l}\text { Data di } \\
\text { database }\end{array}$ & $\begin{array}{l}\text { Tombol } \\
\text { hapus }\end{array}$ & Diterima \\
& $\begin{array}{l}\text { terhapus } \\
\text { dan tampil } \\
\text { pada data } \\
\text { sang ada }\end{array}$ & $\begin{array}{l}\text { dengai } \\
\text { yang }\end{array}$ & \\
& diharapkan & \\
\hline
\end{tabular}

\section{c. Pengujian Input Data Pelanggan}

Hasil dari pengujian input data pelanggan dapat dilihat pada tabel 4.4. berikut ini adalah tabel hasil pengujian input data pelanggan :

Tabel 4.3 Tabel Pengujian Input Data Pelanggan

\begin{tabular}{|c|c|c|c|}
\hline \multicolumn{4}{|c|}{ Kasus dan hasil uji input data pelanggan (data normal) } \\
\hline $\begin{array}{l}\text { Data } \\
\text { Masukan }\end{array}$ & $\begin{array}{l}\text { Yang } \\
\text { Diharapkan }\end{array}$ & Pengamatan & Kesimpulan \\
\hline $\begin{array}{l}\text { Cek nama } \\
\text { pelanggan } \\
\text { login }\end{array}$ & $\begin{array}{l}\text { Tampil } \\
\text { nama } \\
\text { pelanggan } \\
\text { yang login }\end{array}$ & $\begin{array}{l}\text { Sesuai } \\
\text { dengan } \\
\text { yang } \\
\text { diharapkan }\end{array}$ & Diterima \\
\hline $\begin{array}{l}\text { Mengisi } \\
\text { nama } \\
\text { pelanggan }\end{array}$ & $\begin{array}{l}\text { Dapat } \\
\text { masuk ke } \\
\text { menu } \\
\text { utama } \\
\text { pelanggan }\end{array}$ & $\begin{array}{l}\text { Pengisian } \\
\text { sesuai } \\
\text { dengan } \\
\text { yang } \\
\text { diharapkan }\end{array}$ & Diterima \\
\hline $\begin{array}{l}\text { Proses } \\
\text { pembelian }\end{array}$ & $\begin{array}{l}\text { Dapat } \\
\text { masuk ke } \\
\text { halaman } \\
\text { belanja }\end{array}$ & $\begin{array}{l}\text { Pengisian } \\
\text { sesuai } \\
\text { dengan } \\
\text { yang } \\
\text { diharapkan }\end{array}$ & Diterima \\
\hline $\begin{array}{l}\text { Klik } \\
\text { tombol } \\
\text { beli }\end{array}$ & $\begin{array}{l}\text { Dapat } \\
\text { masuk ke } \\
\text { halaman } \\
\text { keranjang } \\
\text { belanja }\end{array}$ & $\begin{array}{l}\text { Pengisian } \\
\text { sesaui } \\
\text { dengan } \\
\text { yang } \\
\text { diharapkan }\end{array}$ & Diterima \\
\hline $\begin{array}{l}\text { Klik } \\
\text { tombol } \\
\text { cek out }\end{array}$ & $\begin{array}{l}\text { Data } \\
\text { tersimpan } \\
\text { ke dalam } \\
\text { database } \\
\text { dan } \\
\text { muncul } \\
\text { data total } \\
\text { harga } \\
\text { barang } \\
\text { yang belum } \\
\text { termasuk } \\
\text { ongkos } \\
\text { kirim dan } \\
\text { langkah- } \\
\text { langkah } \\
\text { selanjutnya }\end{array}$ & $\begin{array}{l}\text { Tombol } \\
\text { simpan } \\
\text { sesuai } \\
\text { dengan } \\
\text { yang } \\
\text { diharapkan }\end{array}$ & Diterima \\
\hline
\end{tabular}




\section{d. Pengujian Tampil Data Pelanggan}

Hasil dari pengujian tampil data barang dapat dilihat pada tabel 4.5 . berikut ini adalah tabel hasil pengujian input data pelanggan :

Tabel 4.3 Tabel Pengujian Tampil Data Pelanggan

\begin{tabular}{|c|c|c|c|}
\hline \multicolumn{4}{|c|}{$\begin{array}{l}\text { Kasus dan hasil uji input data pelanggan (data } \\
\text { normal) }\end{array}$} \\
\hline $\begin{array}{l}\text { Data } \\
\text { Masukan }\end{array}$ & $\begin{array}{l}\text { Yang } \\
\text { Diharapkan }\end{array}$ & $\begin{array}{l}\text { Pengamata } \\
\mathrm{n}\end{array}$ & $\begin{array}{l}\text { Kesimpu } \\
\text { lan }\end{array}$ \\
\hline $\begin{array}{l}\text { Cek data } \\
\text { pelanggan, } \\
\text { data } \\
\text { produk, } \\
\text { data stok } \\
\text { barang, dan } \\
\text { data } \\
\text { kategori } \\
\text { barang }\end{array}$ & $\begin{array}{l}\text { Tampil data } \\
\text { pelanggan, } \\
\text { data produk, } \\
\text { data stok } \\
\text { barang, dan } \\
\text { data } \\
\text { kategori } \\
\text { barang }\end{array}$ & $\begin{array}{l}\text { Sesuai } \\
\text { dengan } \\
\text { yang } \\
\text { diharapkan }\end{array}$ & Diterima \\
\hline Klik cek out & $\begin{array}{l}\text { Tampil total } \\
\text { harga } \\
\text { barang, kode } \\
\text { pesan dan } \\
\text { langkah } \\
\text { selanjutnya }\end{array}$ & $\begin{array}{l}\text { Cek sesuai } \\
\text { dengan } \\
\text { yang } \\
\text { diharapkan }\end{array}$ & Diterima \\
\hline $\begin{array}{l}\text { Hapus data } \\
\text { produk, } \\
\text { data } \\
\text { kategori, } \\
\text { data stok }\end{array}$ & $\begin{array}{l}\text { Akan } \\
\text { muncul } \\
\text { pertanyaan } \\
\text { "yakin data } \\
\text { akan di } \\
\text { hapus" }\end{array}$ & $\begin{array}{l}\text { Hapus data } \\
\text { sesuai } \\
\text { dengan } \\
\text { yang } \\
\text { diharapkan }\end{array}$ & Diterima \\
\hline
\end{tabular}

\section{Kesimpulan dan saran}

\subsection{Kesimpulan}

1. Pada perancangan sistem informasi untuk media penjualan barang bagi sebuah perusahaan/lembaga merupakan proses yang cukup kompleks dalam penjualan barang dapat memberikan kemudahan pengolahan data dan memudahkan dalam membuat laporan-laporan hasil penjualan perbulannya.

2. Sistem informasi ini dapat membantu dengan mudah dalam mencatat data transaksi penjualan serta media promosi yang efektif bagi perkembangan usaha dagang Purnama Shop. Dimana pada sistem informasi ini sangat berperan penting bagi sarana penjualan barang dengan mudah dan juga mengurangi pekerjaan penjual yang mulanya penjual sangat repot dalam pencatatan data transaksi, data stok dan untuk mempromosikan barang dagangan yang penjual usaha.

\subsection{Saran}

Adapun harapan penulis untuk pengembangan lebih lanjut dari sistem ini adalah sebagai berikut :

1. Penambahan animasi pada program sehingga menambah kesan hidup pada website.

2. Menambahkan biaya ongkos kirim pada sistem informasi untuk media penjualan barang pada Purnama Shop

3. Perbaiki ukuran gambar supaya gambar barang pada sistem kelihatan rapi

4. Keamanan pada Sistem lebih ditingkatkan untuk menghindari serangan hacker apabila aplikasi ini digunakan.

\section{Daftar Pustaka:}

[1] P. D. Bunga, "Perancangan Sistem Informasi Penjualan Pada Toko Ribo Jaya Ambon," vol. 5, no. 1, pp. 13-15, 2012.

[2] L. kardila Deti and H. Mulyono, "Analisis Dan Perancangan Sistem Informasi Penjualan Dan Pemesanan Plywood Berbasiskan Web Pada PT. Kumpeh Karya Lestari Jambi," Anal. Dan Peranc. Sist. Inf. Penjualan Dan Pemesanan Plywood Berbasiskan Web Pada PT. Kumpeh Karya Lestari Jambi, vol. 2, no. 1, pp. 327-344, 2017.

[3] S. Kurniawan and S. Iriani, "Perancangan Sistem Informasi Penjualan Helm Pada Toko Helm Swaka Pacitan," IJNS - Indones. J. Netw. Secur., vol. 4, no. 3, pp. 13-18, 2015.

[4] S. N. Mandiri and U. P. I. Yai, "Berbasis Web Pada Toko Ilham Cellular Jakarta," Ilm. Fifo, vol. VIII, no. 2, pp. 161-172, 2016.

[5] V. N. Nore, "Perancangan Sistem Informasi Penjualan dan Pemesanan Produk Berbasis Web. Tugas Akhir Universitas Widyatama.," Skripsi, pp. 1-111, 2013.

[6] Joiyanto, "Sistem Informasi Strategik untuk Keunggulan Kompetitif". Andi Offset, Yogyakarta. 2006. 